\title{
Religion and Social Capital of Citizenship: Bogor Islamic Community in a Globalizing World Development
}

\author{
Dundin Zaenuddin \\ Centre for Society and Culture, Indonesian Institute of Sciences \\ $<$ dundezen@gmail.com>
}

\begin{abstract}
Democratization is a globalized agenda of development that needs to be developed by the Indonesian society to achieve a just and prosperous country that is referred to as 'baldatun toyyibatun wa robbun ghofur' (Arabic, literally, "good country under God forgiveness"). Within this framework, Islamic community (Islamic social organization) and other religious organizations are expected to behave kindly as an equal citizen that observe humanistic, pluralistic and tolerant religious social life. In this context, the situation of reciprocal trust, social solidarity, tolerance, equality, social networking even intra and extra-collective cooperation among socio-religious religious communities are expected to be more natural and sustainable. However, citizenship social capital still need to be develop through internalization and socialization. This research is based on the theories of Habitus of Bourdieu and Gellner's Typology of Social Organization and Kymlicka's Multicultural Citizenship. This research also use other sociological theory namely the social capital theory of citizenship from Putnam, Coleman, Uphof, and religion-state relations theory from Boland, Menchik and Riaz Hassan. This research is qualitative with a multidisciplinary approaches of Sociology, Political Science, and History. The research findings show (1) the cosmopolitanism of the Bogor society is the factor that the various Islamic social organizations are accepted; (2) The social capital type of citizenship of Islamic social organizations is formed due to differences in religious and political orientation which are the resultant understanding of the texts and its religious culture; (3) Nahdhatul Ulama and Muhammadiyah with a moderate religious orientation (washitiyyah) have citizenship social capital that is persistent with democracy, while Hizbut Tahrir Indonesia and Front Pembela Islam with a fundamentalist religious style (ushuliyyah) have civic social capital that is resistant to Pancasila democracy.
\end{abstract}

Keywords: religion, social capital of citizenship, Islamic community, social organizations, civil society, social movements 


\section{Introduction}

Bogor was historically as a capital city of Pakuan Pajajaran kingdom which is another name for the Hindu Kingdom of Sunda kingdom. The word itself comes from the word Pakuan Pakuwuan meaning city. In the past, in Southeast Asia have a custom royal name with the name of its capital. Some records say that the kingdom was founded in 923 by Sri Jayabhupati, as mentioned in the inscription Trance Tread (1030 AD) at village Pangcalikan and Bantarmuncang, the banks Cicatih, Cibadak.

Previously, Hindu was a dominant religion in this area before Islam. Nowadays, majority of population $(95 \%)$ are muslim. However, one cannot ignore that the hybrid culture and cosmopolitan society of Bogor is resulted from long history of societal dynamics of this city. Empirically, Bogor as reflected at the national level of Indonesia is a very plural nation both of regarding the religions and ethnicity of the population. As a pluralistic nation, religious tolerance, namely the willingness of people to respect each other and accept the existence of sects and adherents of other religions, is a very important issue in the life of the Indonesian people. Recognition of social-religious plurality and tolerance is very strategic to consolidate Pancasila democracy and as the basis of the better off Indonesian society.

In such an Indonesian context, the issue of tolerance becomes so an important issue in the the current trend, namely the emergence of the phenomenon of religious intolerance. In certain circles, growing feelings of self-righteousness and consider other schools as heretics and even infidels (takfir) and must be removed. As a result, social norms and rules which are the basis of shared life are less obeyed, and violence between religious groups has increased. This occurs not only between religions, such as cases of religious violence that have occurred in Poso or Ambon or on a small scale occur in Tanjung Balai*, but sociologically it also occurs intrareligious conflict as experienced by certain mainstream Islamic groups, with the Shiite and Ahmadiyah communities, Salafiyah worshipers in West Nusa Tenggara, the sealing of the Jama'ah Islamiyyah mosque in West Sumatra, or anarchist attacks on the Ahmadiyya community. All these events showed the absence of tolerant collective social attitudes and behaviors that guarantee for peaceful co-existence of different religious and ethnic groups. This phenomenon is of course ironic, because religious people should be

\footnotetext{
* The incident that occurred on July 29, 2016 was triggered by a complaint of a Chinese woman named Meliana over the sound of the call to prayer from the mosque located in front of her house. Then the mosque management confirmed the complaint to Meliana, who at that time actually showed her anger. It was reported that Meliana had apologized, but apparently later the news was spread through social media that there had been harassment by Meliana which resulted in a period of damaging temples and temples in the port city.
} 
the most collective agents who affirm mutual sympathy and respect among others.

The above socio-religious phenomena show the low appreciation of certain religious communities towards positive norms, as well as the lack of efforts to revitalize humanistic and tolerant norms of religious social life. This phenomenon indicates that cultural and structural factors play a very important role, and therefore need to be studied and analyzed. Theoretically it can be assumed that social conflicts occur because of what is called social capital of citizenship ${ }^{* *}$ is not yet developed in the lives of some Indonesian people, aside structurally, the principles of good governance ${ }^{* * *}$ also not yet fully implemented.

The above proposition can be further explained through the fact of research findings which show that some Indonesian people are still relatively intolerance. Regarding political life, for example, which is an important

\footnotetext{
** The incident that occurred on July 29, 2016 was triggered by a complaint of a Chinese woman named Meliana over the sound of the call to prayer from the mosque located in front of her house. Then the mosque management confirmed the complaint to Meliana, who at that time actually showed her anger. It was reported that Meliana had apologized, but apparently later the news was spread through social media that there had been harassment by Meliana which resulted in a period of damaging temples and temples in the port city

*** The concept of good governance, has a relational dimension because it is a set of relations between civil society and the government that practices to maximize the common good (the common good). Some of the characteristics that must be upheld include: transparency, effectiveness, responsiveness, openness, submission to the rule of law, acceptance of diversity (pluralism) and accountability
}

requirement for the creation of a democracy, Indonesian society can be categorized as less tolerant. A national survey showed that the majority of Indonesians (67\%) expressed hatred, and were therefore unwilling to coexist with other socio-political and religious groups such as Jews (7\%) and Christians (3\%). Specifically for Christians, members of the community allow worship services in the area around the respondent's residence (31\%), and if in the neighborhood a church $(40 \%)$ is established.[1]

Likewise, a similar picture occurs regarding mutual trust among citizens (interpersonal trust), a political culture of society that can also have a positive impact, or vice versa, for the creation of democracy in Indonesia. In this case, the political culture of the Indonesian people is not very supportive. Only $29 \%$ said they always or often believed in others. In general, society states that everyone must be careful of others, do not easily believe (86\%). This proportion is very large, and shows low political culture for good governance.[1]

This paper will look at the relationship between the religious culture and the social capital of citizenship among Islamic social organizations such as Muhammadiyah, Nahdhatul Ulama (NU), Hizbut Tahrir Indonesia (HTI), and Front Pembela Islam (FPI) or Islamic Defenders Front in Bogor. Muhammadiyah is a mainstream representation of 
Islam with a modernist orientation and moderate political attitude.

Whereas NU is a traditional Islamic social organization and tends to have moderate ppolitical attitude. Meanwhile, HTI is considered as radical and fundamentalist morganization that advocates the Caliphate and rejects democracy. The FPI is also considered 'radical' because the organization sometimes carry out 'sweeping' which act violently against immoral places, though in fact in terms of religious understanding, this group identifies itself as ahlusunnah wal jama'ah like NU.

\section{Social Capital of Citizenship}

Citizenship social capital includes the following elements: 1). Reciprocal Trust, namely thinking, acting and acting positively towards fellow citizens; 2). Solidarity is mutual feelings, interests and goals with fellow citizens; 3 ). Tolerance is willingness to tolerate differences of opinion, beliefs, behavior habits; 4). Equality appreciates equality among fellow citizens and equal access to sources of life (such as social, cultural, political economy); 5). Social Networks: and Organizations (Associations), namely forums or organizations that serve as media for social relations; and 6). Participation (Civic Engagement) and Cooperation, namely the participation of a person in his community and conducting collective cooperation to achieve the common good and recognize diverse ethnic interests, as can be seen in the following fig. 1.

The eight elements of citizenship social capital will be seen among

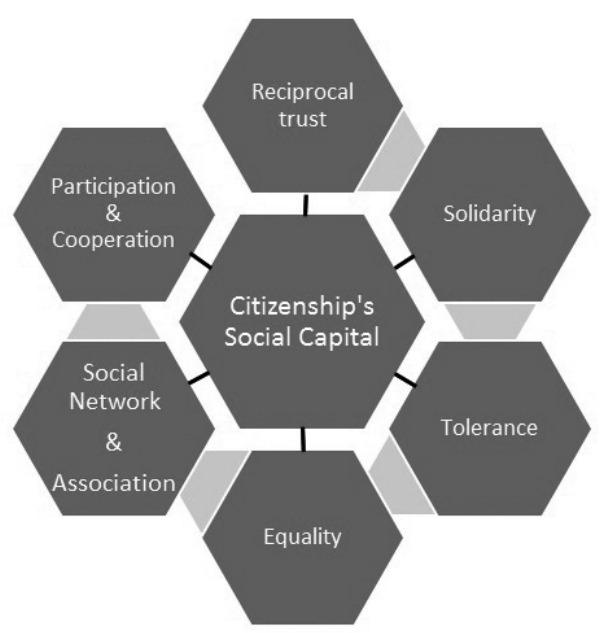

Fig. 1 Elements of Social Capital

Islamic social organizations in Bogor. The assumption is that the level of citizenship social capital within Islamic organizations is formed by an understanding of the values that originate in the text and their perceptions of the context of socio, cultural, political and economic configurations. Understanding the text and configuration of the context can be both a motivating and inhibiting factor for the development of citizenship social capital. The level of citizenship social capital will in turn affect the formation of a multi-cultural democratic society. If the culture of citizenship is good, it will grow well with a multicultural democratic society, and vice versa. 
Empirically, the social capital of citizenship can be grown among religious social life. This relates to what Bourdieu calls habitus. Habitus is a mental or cognitive structure, which is used by actors to deal with social life.[3] Habitus is a product of history, as a legacy from the past influenced by the existing structure.[4] Certain individual habits are obtained through life experiences that are internalized, for then they use to feel, understand, realize and value the social world.[3]

This habitus of civilized life was also promoted by the Prophet Muhammad among Medina community. Historical facts show that the social capital of citizenship can grow well in a society led by the Prophet Muhammad at the beginning of Islam and is now referred to as an ideal form of society. The Prophet had established the Muslim habitus which in the Nurcholish Madjid statement was "Genuine engagement of diversities within the bonds of civility" ${ }^{\prime * * * *}$. Even the ideas and practices of democracy at the time of the Prophet were considered to be very advanced beyond the development of his era. At that time, differences in religions such as Islam, Judaism and Christianity were actually used as social capital for the development of the community in sustaining state capacity which was directly led by the Prophet. It is this modern way of

**** see Nurcholish Madjid in Republika, on August 10, 1999 managing a state led by the Prophet Muhammad that Ernest Gellner (1982), a well-known sociologist, later said that Islam can maintain its system of faith in the modern age without doctrinal interference. This is because according to him, purification of the aqidah (basic tenets) can go hand in hand with the process of modernization. This compatibility is due to pure teaching Islam which is egalitarian (affirming the equality of humanity) and promote science and research. This was also shown by Marshall G.S Hodson (1974), a historian of Islamic experts that the XVI century innovative investment in humanity and material which was a transmutation factor of modern technological age in the Western world was in fact already owned by medieval Muslim communities

According to Hikam (1996: 3) communities with solid citizenship social capital as seen in civil society are marked by free communication transactions by communities, because in this arena independent actions and reflections are ensured, not constrained by conditions of official political institutions. [5] So here it is possible for negotiations to attain the common good while still obeying the applicable law, as a par excellence characteristic of civil society in the conception of Nurcholish Madjid. There are at least three important elements that determine the strengthening of civil society, namely the existence of networks of 
social relations, reciprocal trust and the willingness to reciprocate. Robert Putnam's research findings in Italy, as reported in his book Making Democracy Work: Civic Traditions in Modern Italy,[6] for example, have tried to prove that economic progress and social welfare in an area are very dependent on how far members of society have an awareness of the importance of engaging in a network of institutional relationships to achieve shared goals. The northern Italian region in general, according to Putnam, achieved a high level of social and economic success because most members of the community have long had a tradition to be involved in a wide network of social relations, so various social, political and economic problems were solved successfully through institutional collaboration. In contrast, in southern Italy there was no such tradition. Communities lived in groups that run individually, separated from one another and compete unfairly. This condition was concluded by Putnam as the most decisive cause why this region could not achieve economic progress in multicultural democracy as happened in northern Italy.

For the condition of Indonesia, Hefner (2000), points to the existence of a strong tradition among Muslims to associate. He specifically mentioned Muhammadiyah and NU as two large and well-established organizations where Muslims practiced associational culture, had shown the face of a peaceful Islam and played a role in promoting plurality and democracy in this country. In relation to the social capital of citizenship, he said that

"the pluralist civic wing of the Muslim community believes that only through decisive rejection of Islamic politics (in the sense of formal political parties) and commitment to a pluralistic, democratic, and civil Indonesia, the nation can go forward "..[7]

Thus, differentiation of religion and state is an important factor to nurture citizenship social capital. Research by Riaz Hassan (2006) shows that the pattern of differentiation that differentiates religion and politics (the case of Indonesia) shows that the trust between citizens is relatively higher than that of integration (the case of Pakistan).[8] Similarly it is also argued by Boland, as a 'Pancasila State with a Ministry of Religion', Indonesia chose a middle way between 'the way of Turkey' and the founding of an 'Islamic State. A 'secular state' would perhaps not suit the Indonesian situation; an 'Islamic State,' as attempted elsewhere, would indeed tend 'to create rather that to solve problems.' For this reason the Indonesian experiment deserves positive evaluation.[9] According to Menchik, in this divine nationalist Indonesia (Indonesia's godly nationalists), the presence of religious organizations in the public sphere is very beneficial for the public good (public good), rather than the secular-liberal concept that 
the presence of religion in the public sphere is a threat to freedom and modernization.[10]

Meanwhile, as an effort to conduct empirical analysis and the basis for creating categories can be seen in Table 1 below. In this table, the beliefs, norms and values commonly derived from religious teachings are a cultural aspect of social capital conception that has come to the attention of social scientists. Citizenship social capital is a cultural domain related to social organizations that dynamically determine relationships horizontally and vertically. The growth of reciprocal trust, solidarity, willingness to help and cooperation is a sign of the existence of citizenship social capital.[11]

To refer to the findings regarding this matter can be explained as follows. According to research results, in America, the church acts as a social network that encourages community volunteerism: religious organizations encourage opportunities to serve, both inside and outside the scope of their groups, providing personal contacts, committees, telephone numbers, meeting rooms, transportation and whatever makes good intentions become real actions.[12] Previous research also noted that religious volunteers are more motivated than those who are not religious in terms of their involvement in achieving the common good.[13] He also showed that church members were more eager to give money and time, including secular actions.[14] For example, they give 50 trillion every year as donations; this amount is three times greater than the money donated for education or five times greater than for health.[15] In terms of political involvement it was also shown that church members were more likely to vote in elections.[16] It was also noted that reports of successful efforts to build residential settlements were more indicated by religious institutions or

Tabel 1. Category of Social Capital[6][11]

\begin{tabular}{lll}
\hline \multicolumn{1}{c}{ Category } & \multicolumn{1}{c}{ Structural } & \multicolumn{1}{c}{ Cultural } \\
\hline Manifestation & $\begin{array}{l}\text { Roles and Rules, Network } \\
\text { and personal relationship, } \\
\text { procedure and precedent }\end{array}$ & Norms, Values, Attitudes, Tenets \\
\hline Domain & Social Organization & $\begin{array}{l}\text { Element of Citizensip's Social } \\
\text { Capital: Trust, Solidarity, Tolerance, } \\
\text { Equality, Network, Association, } \\
\text { Participation and Cooperation. }\end{array}$ \\
\hline Dynamic Factors & Horizontal Relationship & $\begin{array}{l}\text { Trust, Solidarity, Cooperation, } \\
\text { Generosity }\end{array}$ \\
& Vertical Relationship & Genofion to cooperate, beneficial for all \\
\hline General Elements & Expectation &
\end{tabular}


by devout people (Coleman, 2003: 34; Schambra 1994: 32).[17] Other findings also show that religious institutions play an extraordinary role in developing one's ability as citizens (civic skills).

Furthermore, Putnam's conception of the two sides of the equilibrium seems to be relevant. He conceptualizes the existence of two circles, namely virtue circles and vicious circles. The circle of virtue is one side of social equilibrium characterized by high cooperation, mutual trust, reciprocity, civic engagement for the common good. This condition can be said as the persistence of citizenship social capital. While the vicious circle (negative) is characterized by betrayal, distrust, denial, exploitation, chaos, isolation, and setback. These elements reinforce one another and give birth to resistance to citizenship social capital. It can be said that collective cooperation between various Islamic and religious communities in general will be more prevalent in societies that are colored by the positive equilibrium side.

Putnam's conception indicates that citizenship social capital will develop if equality before the law are enforced, the functioning of social norms, the establishment of cooperation, mutual trust, the running of reciprocity and the active involvement of each Islamic group to obtain their rights as citizens in the framework of achieving the common good. This conceptual framework from Putnam is useful for the study of the functional relationship of citizenship social capital of Islamic social organizations with Pancasila multicultural democracy.

As far as the concept of citizenship is concerned, in Marshall theory, there are three dimensions of rights contained therein, namely civil, political and social rights. Civil rights relate to basic issues such as freedom of speech and the right to obtain access and fair treatment in the legal system. Political rights are not only about the rights in elections but also greater access to political institutions to articulate their interests. Whereas social rights relate to access to a social security system, where every citizen has the right to obtain at least a basic level of welfare which must be fulfilled by the state in a state of unemployment, illness or misfortune. However, it should be immediately added here that there are cultural rights namely rights relating to cultural identity, religion, language and customs, which are absent in Marshall theory because of the relatively homogeneous context of British society in terms of religion at that time. According to Turner, active citizen is a must to achieve these rights.[18]

Furthermore, the link between citizenship social capital and democratization is inspired by multicultural democratic theory. This theory initially questioned whether minorities have the right to maintain 
their cultural institutions and can legally maintain their cultural identity.[19] [20][21][22] This theory discusses social, civil and political rights, in addition to the accommodation rights of the institutional structure of the state for minorities. This multicultural democracy theory further states that there is a positive correlation or significant relationship between political integration with mutual trust, tolerance and solidarity. Empirically, there is a positive correlation between social political participation and mutual trust in politics (political trust) on the one hand and the presence of a network of community organizations on the other. [23]

\section{Religion, Politics and Social Capital of Citizenship}

There are three levels of citizenship social capital of Islamic Social Organizations (ISOs) in Bogor, namely persistent, not so persistent and resistant citizenship social capital to democracy. This is related to the attitudes and behavior of the community or actors towards the text and the context and characteristics of a social organization. Characteristics of ISOs are related to the religious and political orientation of the ISOs concerned.

As seen in fig. 2, there are four characteristic patterns of Islamic CSOs in Bogor, which reflect patterns in the national context as well. Nahdhatul Ulama (NU) is an organization that understands texts interpretatively and to some extent metaphorically, with a traditional tendency in religious orientation because it follows the opinions of medieval scholars written in the 'yellow' book (four madzhabs in fiqh orientation). Whereas the political orientation of this ISOs tends to be moderate and conservative because it has accepted the final form of the Republic of Indonesia based on Pancasila. Meanwhile, Muhammadiyah is a modernist organization because it is concerned with ijtihad and does not practice taqlid or become a follower of certain schools of thought ( $m a d z h a b$ ). Similarly, Muhammadiyah is also a moderate conservative in political orientation and has accepted the final form of the Republic of Indonesia and mentions it as darul 'ahd wa shahadah (founding fathers' agreement).

FPI is also categorized as a mass organization which is similarly traditional as NU, but this social organization tends to resort to violence when confronted with social immoral actions judged to be incompatible with Islamic teachings. This organization usually sweeps it if its report to the authorities responsible for dealing with violations of the law has not received a serious response from the security forces. This organization is also labeled as radical because it tries to formalize Islamic Sharia. Meanwhile, HTI is a social organization though it considers its self as political organization that 
tends to be scriptural in understanding the texts, including interpreting commands to implement Islam Sharia. It is called radical or fundamentalist because it fights for the realization of the Islamic caliphate or Islamic global state as the final form of Islamic politics and it does not accept democracy as well. This organization is also very active to formalize Sharia. According to this social organization, the social context has not been accommodating of Islamic sharia and is considered to exclude the formalization of Islamic law.

In various studies on citizenship social capital, experts argue that citizenship social capital is influenced by texts and context. Understanding the texts here is interpreted as a subjective understanding of the sources of religious teachings either the results of one's own understanding (ijtihad) or following the opinion of the cleric or religious teacher (taqlid or ittiba'). While the context is subjective understanding both individually and collectively of the structural-objective conditions (socio-cultural, economic and political configurations).

This theoretical constructions seem to be verified by the reality of Islamic social organizations in Bogor. Fig. 3 shows that NU and Muhammadiyah for example in understanding texts are interpretative and metaphorical, so there

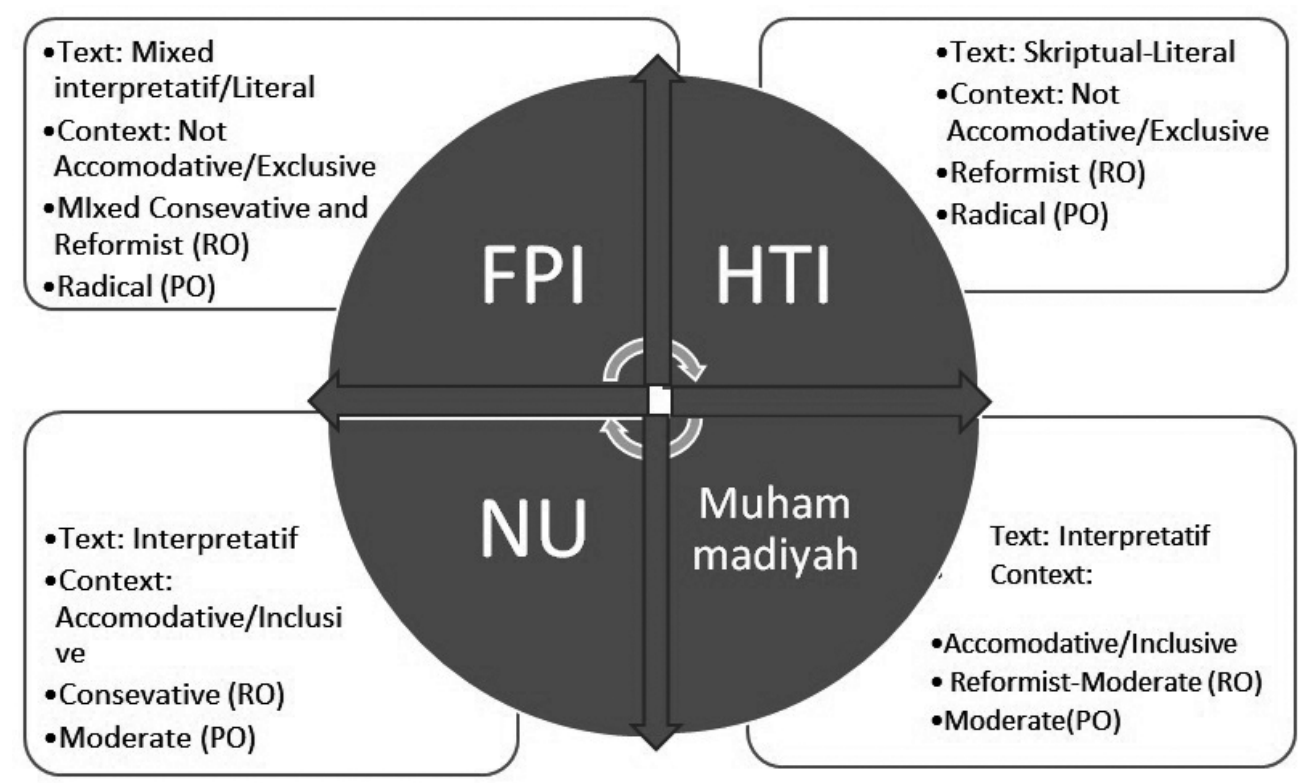

Fig. 2 Four Pattern of Religious and Political Orientation. Vertical: Political Orientasion (PO): Conservative-Radical. Horizontal: Religious Orientation: Moderate conservative-Reformist/radical.[24] 
is flexibility in understanding the texts or the scriptures. Understanding religion in this view places Islam in accordance with the times and the context in which it lives. No matter how different the two camps are about being traditional or modernist, these two organizations are moderately conservative in their political orientation considering the Unitary State of the Republic of Indonesia based on Pancasila as the final form of the state. Both organizations also tend to consider that the relative socio-economic conditions has accommodated several Islamic teachings and tend not to support the formalization of Islamic law (sharia). Both of these organizations prefer cultural strategies through education and dakwah rather than political move to implement sharia.

The religious and political orientation of NU and Muhammadiyah provides relatively persistent consequences for citizenship social capital. Reciprocal trust internally and externally with other organizations including non-Islamic organizations by establishing communication relations in interfaith forums are promoted. With these conditions, solidarity and tolerance are also maintained and nurtured. The active engagement in the interfaith forum also shows that the two social organizations upholds equality among all citizens and equal before the law.

NU and Muhammadiyah also have extensive networks. If NU relies on Islamic boarding schools (pesantren) network as an educational institution that reaches to the countryside, Muhammadiyah relies on a network of modern schools. Both of these large organizations are also active in social media in establishing communication with various groups. Both of these organizations are also active in the local MUI in promoting moderate Islam and in several formal state institution to articulate social cultural engagement.

In terms of participation and cooperation, NU has a very important role in the area of education, namely pesantren which in contemporary development not only hold religious education solely with the yellow book as a source of teaching, but also open classy schools both in the form of Madrasas which are affiliated with the Ministry of Religious affairs, as well as public schools that are affiliated with the Ministry of Education and Culture. These two trends are also implemented by Muhammadiyah. At first, Muhammadiyah focused more on modern education in the form of classes, but later this modern organization also organized pesantren as an appreciation of Islamic traditions in the archipelago. Another prominent participation was Muhammadiyah's charitable endeavors in the field of health and the economy of the people. In the health sector, for example, this organization has a number of hospitals and health clinics spread 
across various corners of Bogor (MPI, 2015). In the favorable conditions like this, collaboration with various parties both with other social organizations or with the government is also carried out so that all programs can be implemented successfully. Thus, citizenship social capital of both social organizations with the support and articulation of its various elements and aspects, thus, become persistent towards Pancasila multicultural democracy.

Conversely, with the scripturalistliteralist attitude toward the texts and negative perception of the context resulting in some radical attitudes and actions as performed by HTI and to smaller extent by FPI as can be seen in the fig. 4 and 5. Understanding the texts in this way fosters a fundamentalist attitude which tends to give birth to behave absolutely, namely the attitude that the group's understanding is considered the most correct while others are wrong. Caliphate proposed by HTI, for example, are the only game in town

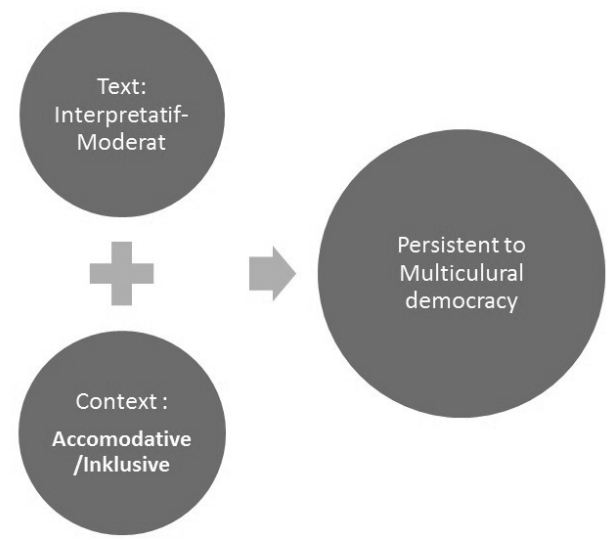

Fig. 3 NU's and Muhammadiyah Citizenship Social Capital (thariqah) to implement sharia. This results in a low level of tolerance and low level of collective cooperation within Islamic groups and with other non Islam social organizations. They consider non muslim people as the second citizen though their lives and wealth have to be protected. Their low level of tolerance shows a low degree of citizenship social capital. Meanwhile, in terms of the context, this group perceives it as a situation that is not conducive to Islam implementation. They, for example, always feel injustice happening in various sectors of life including in terms of accessibility to education and health facilities provided by the government. This situation will be psychologically pressure for the group to only emphasize solidarity between Muslims or even just their communities to support what they want. To fight for the interests of their groups, they certainly need an ideology. This group then has high expectations on the formalization of Islamic law which is expected to realize their wishes or aspirations. They reject capitalism and communism, and for HTI, Pancasila are not acceptable for the umma. HTI argues that Pancasila democracy is human creature, while sharia is created by God. A further social implication is that this group has a low desire to have a dialogue with other social grouping or other cultural stakeholders. This group, for example, is not part of the local ulama council (Majelis Ulama 
Indonesia, MUI Bogor). Both of these organizations also use networks and associations only for internal groups.

However, HTI is very well known to the public and is often involved in demonstrations condemning capitalism and colonialism in public streets or public meetings. While FPI is known to the Indonesian public because it is very involved with social assistance when certain groups are affected by natural disasters. Interestingly, this assistance was also given to non-Muslims people. Nevertheless, citizenship social capital of HTI and fairly low because of exclusive attitude toward its fellow non muslim citizens. In a lower degree of tolerance, citizenship social capital of FPI are also generally considered resistant to multicultural democracy because this organizations' agenda is to formalize Islamic sharia through formal legislation in national level as well as regional level (PERDA). However FPI

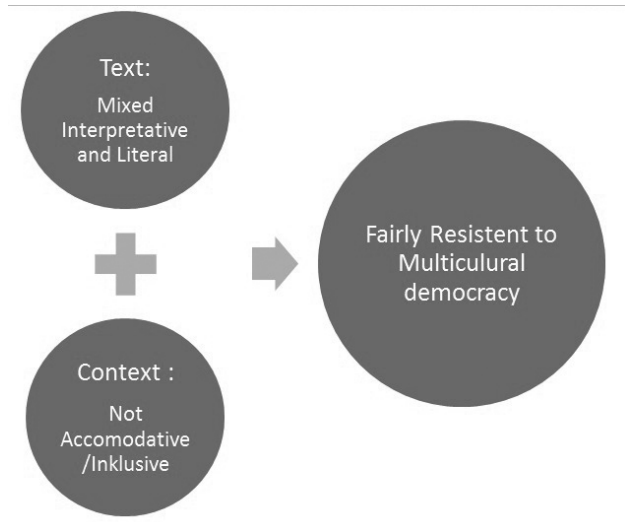

Fig. 4 FPI's Citizenship Social Capital is considered as less radical than HTI because this organization still formally accept the existing state of Republic of Indonesia and its conservative religious orientation of ahlusunnah wal jama'ah (aswaja) ideology. It is for the reason, that the government has not revoked this organization until now, and at the time it has not been registered as well.

\section{Conclusion}

The research findings show that: (1) the cosmopolitanism of the Bogor society is the factor that the various Islamic social organizations are accepted; (2) The social capital type of citizenship of Islamic social organizations is formed due to differences in religious and political orientation which are the resultant understanding of the texts and its religious culture; (3) Nahdhatul Ulama and Muhammadiyah with a moderate religious orientation (washitiyyah)

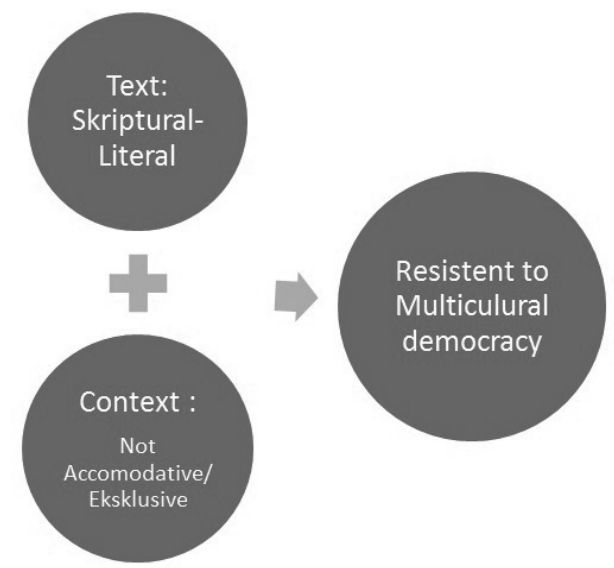

Fig. 5 HTI's Citizenship Social Capital 
have citizenship social capital that is persistent towards democracy, while Hizbut Tahrir Indonesia and Front Pembela Islam with a fundamentalist religious style (ushuliyyah) have civic social capital that is resistant to democracy; (4) Nahdhatul Ulama and Muhammadiyah see the context as friendly to sharia and do not aspire formalization, while Front Pembela Islam and Hizbut Tahrir Indonesia see the context as unfriendly and aspire the formalization of sharia.

In general conclusion, the way of understanding the texts and context has caused the different types of citizenship social capital and its articulation. Religion and state differentiation has also caused NU's and Muhammadiyah's citizenship social capital persistent to democracy, while state and religion integration advocated by Front Pembela Islam and Hizbut Tahrir Indonesia has caused their social capital become resistant to Pancasila democracy.

Finally, this paper suggests recommendations to develop Pancasila multicultural democracy, the two Islamic teaching reources namely Quran especially as the first resource, and also Hadits needs to be interpreted intellectually and to some extent metaphorically with considering public interests (maslahah) in mind. Through this approach, Islamic teachings could be compatible with every time and place.

It is also recommended that the government should relentlessly develop social situation compatible to the ideal norms (the common good) and include special need for some social organizations to minimized oar hinder radicalization among certain social organizations.[]

\section{References}

[1] Mujani, Saeful, 2002. Islam dan Good Government, IAIN Syarif Hidayatullah. Jakarta, PPIM. p: $19-20$

[2] Mujani, Saeful, 2002. Islam dan Good Government, IAIN Syarif Hidayatullah. Jakarta, PPIM. p: 21-22

[3] Ritzer, G. dan D. J. Goodman. 2003. Teori Sosiologi Modern. [translated by: Alimandan]. Jakarta: Prenada Media. p: 522

[4] Bourdieu, P. 1990. The Logic of Practice. California: Stanford University Press. p: 54

[5] Hikam, MAS. 1996. Demokrasi dan Civil Society. Jakarta: LP3ES. p:6.

[6] Putnam, Robert, 1993. "The Prosperous Community: Social Capital and Public Life", The American Prospect, Vol. 13, pp. 35-42.

[7] Hefner, Robert W. 2000. Islam Pasar Keadilan: Artikulasi Lokal, Kapitalisme, dan Demokrasi. Yogyakarta: LKIS. p: 227.

[8] Hassan, Riaz. 2006. Keragaman Iman, Studi Komparatif Masyarakat Muslim, terj. 
Jakarta: Raja Grafindo Press.

[9] Bolland, B.J. 1982. The Struggle of Islam in Modern in Indonesia. Leidden: Martinus Nijholf.

[10] Menchik, J. 2016. Islam and Democracy in Indonesia. New York: Cambridge University Press.

[11] Uphoff, Norman, 2000. "Understanding Social Capital: Learning from the Analysis and Experience of Participation” (Makalah pada Staff Seminar, Mansholt Institute, Wageningen, 13 September).

[12] Wuthnow, Robert. 1994b. God and mammon in America. New York: Free Press. p:242

[13] Wuthnow, Robert. 1991. Acts of compassion: Caring for others andhelping ourselves. Princeton. New Jersey: Princeton University press. p: 325.

[14] Wuthnow, Robert. 1996. The religion industry: Further thoughts onproducing the sacred. In Society for the scientific study of religion annual meeting. Nashville: Tennessee. p: 87.

[15] Wuthnow, Robert. 2003. Can religion revitalize civil society? An institutional perspective. In Religion as social capital: Producing the common good, ed. Corwin E. Smidt:191-209. Waco, TX: Baylor University Press. p: 208.

[16] Wald, K., L. Kellstedt, and D. Leege. 1993. "Civic involvement and political behavior". In Rediscovering the religious factor in American politics, ed. D. Leege and D. Kellstedt. Armonk, NY: M.E. Sharpe. p: 49.

[17] Coleman, John A. 2003. Religious social capital: Its nature, social location, and limits. In Religion as social capital: Producing the common good, ed. Corwin E. Smidt: 33-49. Waco, TX: Baylor University Press.

[18] Turner, Bryan. S. 1990. “An outline of a Theory of Citizenship”. Sociology, vol. 24:3, page: $89-217$.

[19] Young, C.M. 1990. Justice and the Politics of Difference. Princeton University Press.

[20] Kukathas, B. 1992. “Are They any Cultural Right?” Political Theory, 20:105-139.

[21] Kymlicka. W. 1995. Multicultural Citizenship: A Liberal Theory of Minority Rights. Oxford: Oxford University Press.

[22] Kymlicka, W dan Norman, W. eds. 2000. Citizenship in Diverse Societies. Oxford: Oxford University Press.

[23] Fenemo, M dan Tillie, J. 1999. "Political Participation and PoliticalTrust in Amsterdam: Civic Communities and Ethnic Networks". Journal of Ethnic and Migration Studies, 25 (4), 703-726.

[24] Gellner, Ernest. 1982. Muslim Society. New York: Cambridge University Press.

[25] Gellner, Ernest. 1995. Membangun Masyarakat Sipil, Prasyarat Menuju Kebebasan,Terj. Ilyas Hasan. Bandung: Mizan. 